\title{
Phytoplankton biomass and production in two Tuamotu atoll lagoons (French Polynesia)
}

\author{
Loïc Charpy* \\ ORSTOM, C.O.M., Traverse de la Batterie des Lions, F-13007 Marseille, France
}

\begin{abstract}
Nutrient concentrations, phytoplankton biomass (chlorophyll a, chl a) and primary production $\left({ }^{14} \mathrm{C}\right.$ uptake) were measured over a $5 \mathrm{yr}$ period $(1990$ to 1994 \} in the atoll lagoons of Takapoto ( 4 yr water residence time; with pearl oyster aquaculture) and Tikehau (0.5 yr residence time; without pearl oyster but with a fishery), French Polynesia. In both atolls, phosphate and silicate concentrations $\left(0.1 \mu \mathrm{M} \mathrm{PO}_{4}\right.$ and $\left.0.8 \mu \mathrm{M} \mathrm{SiO}_{2}\right)$ were lower inside the lagoon than in surrounding oceanic surface waters. Picoplankton $<1 \mu \mathrm{m}$ dominated phytoplankton biomass $(61 \%)$ and productivity $(55 \%)$ in both lagoons. Average assimilation numbers were high (13 $\mathrm{mg} \mathrm{C} \mathrm{mg}^{\prime} \mathrm{Ch}$ ] a h $\left.{ }^{1}\right)$ and average chl a doubling rates of the $<1 \mu \mathrm{m}$ fraction were estimated to be 1.1 and $1.3 \mathrm{~d}^{-1}$ in Takapoto and Tikehau, respectively. Average daily primary production during the 1991 to 1994 period in Takapoto and Tikehau lagoons was estimated to be 0.8 and $0.7 \mathrm{~g} \mathrm{C} \mathrm{m}^{-2} \mathrm{~d}^{-1}$, respectively.
\end{abstract}

KEY WORDS: Nutrients Phytoplankton Production Pearl oyster Atoll lagoon French Polynesia

\section{INTRODUCTION}

Atoll lagoons play an important role in the French Polynesian economy: cultured pearls from pearl oysters cultured in Tuamotu atoll lagoons are French Polynesia's most valuable export. Lagoon productivity studies are necessary to estimate their culture potential. Indeed, the oysters feed only on natural lagoon production and furthermore cannot retain particles $<3 \mu \mathrm{m}$ (Charpy 1994). Primary production of some Polynesian atoll lagoons has been studied since 1974. Takapoto (Sournia \& Ricard 1975, 1976), Tikehau (Charpy-Roubaud et al. 1989, Charpy \& CharpyRoubaud 1990a, b), Scilly (Ricard \& Delesalle 1981), and Mataiva (Delesalle et al. 1985). Two multidisciplinary programs were launched in 1991 to improve knowledge on Tuamotu lagoonal ecosystems: Programme Général de Recherche sur la Nacre (PGRN) in Takapoto $\left(14^{\circ} 30^{\prime} \mathrm{S}, 145^{\circ} 20^{\prime} \mathrm{W}\right)$ and CYcle de $\mathrm{l}^{\prime}$ Energie et de la matière dans les Lagons d'atolls (CYEL) (Charpy 1992) in Tikehau $\left(15^{\circ} 00^{\prime} \mathrm{S}, 148^{\circ} 10^{\prime} \mathrm{W}\right.$ ). The main objective of the PGRN project was to compare

\footnotetext{
•E-mail: charpy@orstom.rio.net
}

current environmental conditions with conditions existing before aquaculture began there and to study the biology of the pearl oyster Pinctada margaritifera The CYEL program is a continuation of the ATOLL program (1982 to 1988), with a special focus on the pelagic microbial loop. The present study fits into the PGRN and CYEL programs.

Here, we present results from primary production experiments carried out over a 5 yr period (1990 to 1994) in 2 lagoons: Takapoto (a closed atoll) and Tikehau (an atoll with a passage). The experiments were undertaken with 2 goals: (1) to estimate the average productivity of the lagoons, and (2) using size-fractionation methods, to estimate relative contributions of phytoplankton sub-populations to community productivity.

\section{MATERIAL AND METHODS}

Study sites. Takapoto is located in the north of the Tuamotu Archipelago. It has a surface area of $74 \mathrm{~km}^{2}$, of which $23 \mathrm{~km}^{2}$ is emerged rim and $51 \mathrm{~km}^{2}$ is lagoon. There is no passage and exchange between ocean and lagoon is by reef flat spillways $(10 \mathrm{~m}$ wide, $10 \mathrm{~cm}$ 
deep). Prevailing winds are from the east. The average depth is $25 \mathrm{~m}$ and the average replacement time for water in the lagoon is $4.2 \mathrm{yr}$ (Sournia \& Ricard 1976). Pearl culture was begun on a regular basis in 1970 .

Tikehau is situated in the northwest of the Tuamotu archipelago; its geomorphological characteristics make it a suitable model of a mid-size open atoll. Tikehau is almost circular (Fig. 1): its widest diameter (NE-SW axis) is nearly $28 \mathrm{~km}$. The reef rim is ca $78 \mathrm{~km}$ long and has a width - taken between the algal ridge and the edge of the lagoon-ranging from less than 300 to $1300 \mathrm{~m}$ (Intes 1984). The lagoon has an area of $400 \mathrm{~km}^{2}$; of this, $91 \%$ has a depth greater than $15 \mathrm{~m}$, while the average depth is $25 \mathrm{~m}$ (Lenhardt 1991). The $25 \mathrm{~km}^{2}$ of islands are intersected by reef-flat spillways which link the lagoon and the ocean; one of these forms a $200 \mathrm{~m}$ wide and $4 \mathrm{~m}$ deep passage at the western end. Except for those in the passage, currents in spillways generally flow into the lagoon at low speed. The average outward flow in the passage is $700 \mathrm{~m}^{3} \mathrm{~s}^{-1}$; therefore, a simple average replacement time for waters in the lagoon is $176 \mathrm{~d}$ (Lenhardt 1991). Fishery is the main resource of Tikehau inhabitants.

Water sampling. Phytoplankton biomass in Takapoto was sampled monthly between 1990 and 1992 at 3 stations (Stns 1, 2 and 3) (Fig. 1). Primary production measurements were performed monthly between March 1990 and November 1990 at these stations. Measurements were also made during June 1991, September and November 1993, and February and November 1994 at 8 stations (Fig. 1). The Tikehau atoll lagoon was sampled for biomass and primary production measurements 7 times between 1991 and 1994 in January and November 1991, March, May and November 1992, March 1993 and October 1994. Six stations were occupied within the lagoon. One of these stations is the lagoon reference station (Stn 3) discussed ear- lier (Charpy \& Charpy-Roubaud 1991). Two stations (Stns 1 and 2) are located windward and leeward. of a reference pinnacle (Charpy \& Harmelin-Vivien 1992) to observe how coral pinnacles may influence lagoonal waters. Water samples were collected with acid-cleaned Niskin bottles at the surface and $5 \mathrm{~m}$ depth intervals to $25 \mathrm{~m}$.

Primary production measurements. Between 2 and 5 subsamples of unscreened sea water (Furnas 1987) were incubated in situ between 10:00 and 14:00 h with $2 \mu \mathrm{Ci}$ of ${ }^{14} \mathrm{C}$-bicarbonate (added with a plastic-tipped micropipette) in $1000 \mathrm{ml}$ borosilicate glass bottles (1990) or $300 \mathrm{ml}$ polycarbonate bottles (1991 to 1995). Special care was taken after 1990 to avoid exposing the samples to bright light. Three bottles were wrapped in black plastic for dark assimilation estimation. In 1990. following incubation, bottle contents were filtered through $10 \mu \mathrm{m}$ Nuclepore filters; pressure heads during fractionation never exceeded 0.004 atm. The filtrates were sequentially refiltered onto $2 \mu \mathrm{m}$ and $0.2 \mu \mathrm{m}$ Nuclepore filters. One of the bottles was filtered directly through a $0.2 \mu \mathrm{m}$ Nuclepore filter for estimation of total production. Between 1991 and 1994, incubation bottles were filtered successively through $3 \mu \mathrm{m}$ and $1 \mu \mathrm{m}$ Nuclepore filters and then $25 \mathrm{~mm}$ Whatman $\mathrm{GF} / \mathrm{F}$ glass fiber filters. One of the bottles was filtered directly through GF/F filters for an estimate of total production. First results for Takapoto indicated that total production and biomass measured using GF/F filters was equal to production and biomass measured using $0.2 \mu \mathrm{m}$ Nuclepore filters (Charpy et al. 1992) To remove inorganic carbon $250 \mu \mathrm{l}$ of $0.5 \mathrm{~N} \mathrm{HCl}$ were added to the filter in the scintillation vial. Twelve hours later, $100 \mu$ l. of Protosol was added to the filter. Radioactivity on the filters was measured with a liquid scintillation counter and corrected for quench by using an internal standard and channels ratio method. Carbon
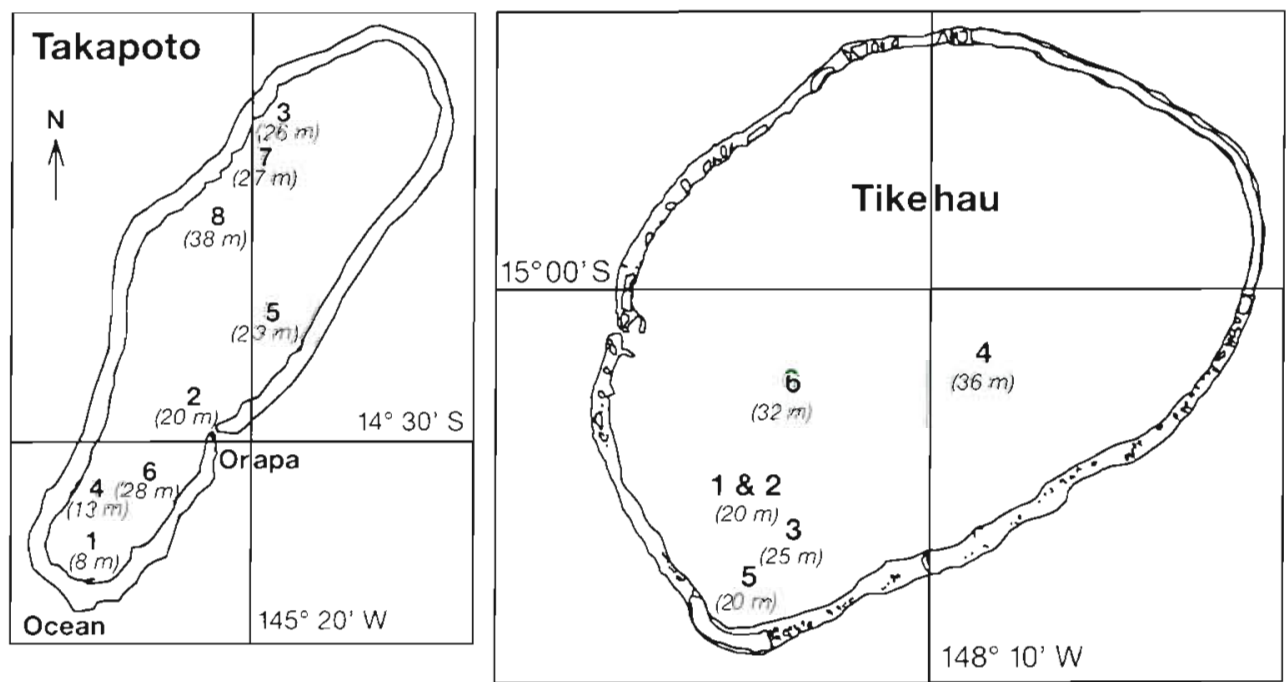

Fig. 1. Locations and depths of stations in Takapoto and Tikehau lagoons (Tuamotu Archipelago 
uptake was calculated using $\Sigma \mathrm{CO}_{2}=90 \mathrm{mg} \mathrm{l}^{-1}$ for the 1990 data and using the $\Sigma \mathrm{CO}_{2}$ calculated from total alkalinity measurements for the 1991 to 1994 data. Areal production was calculated by trapezoidal integration.

Total alkalinity (TA) determinations were performed on acidified sea-water samples by the method of Perez \& Fraga (1987). Total alkalinity data were not corrected for changes in nutrient concentration (Chisholm \& Gattuso 1991). Carbonate alkalinity (CA) was calculated by the equation: $\mathrm{CA}\left(\right.$ meq $\left.\mathrm{l}^{-1}\right)=\mathrm{TA}-\mathrm{BA}$, with $\mathrm{BA}$ (borate alkalinity; meq $\mathrm{l}^{-1}$ ) calculated as:

$$
\mathrm{BA}=\Sigma \mathrm{B}\left[\frac{a_{\mathrm{H}} K_{1 \mathrm{~b}}+2 K_{1 \mathrm{~b}}+2 K_{\mathrm{tb}} K_{2 \mathrm{~b}}}{a_{\mathrm{H}}^{2}+a_{\mathrm{H}} K_{1 \mathrm{~b}}+2 K_{1 \mathrm{~b}} K_{2 \mathrm{~b}}}\right]
$$

where $\sum \mathrm{B}$ is total boron $\left(\mathrm{mmol} \mathrm{l}^{-1}\right)=0.01 \times$ salinity; $a_{I I}$ is hydrogen ion activity $\left(10^{-\mathrm{pH}}\right)$; and $K_{1 \mathrm{~b}}, K_{2 b}$ are the first and second dissociation constants for boric acid. Values for these constants are tabulated as functions of temperature and salinity in Riley \& Skirrow (1975).

Total $\mathrm{CO}_{2}\left(\Sigma \mathrm{CO}_{2}\right)$ was calculated from the equation:

$$
\Sigma \mathrm{CO}_{2}=\mathrm{CA}\left[\frac{K_{1 c} a_{H}+K_{1 c} K_{2 c}+a_{\mathrm{H}}^{2}}{K_{1 c} a_{\mathrm{H}}+2 K_{1 \mathrm{c}} K_{2 c}}\right]
$$

where $K_{1 c}, K_{2 c}$ are the first and second dissociation constants for carbonic acid (Riley \& Skirrow 1975).

Chl a determination. Chl a concentrations were determined by fluorometry (Yentsch \& Menzel 1963). For chl a determinations, $250 \mathrm{ml}$ of water sample were size fractionated by the same methods as productivity samples: they were successively filtered through $3 \mu \mathrm{m}$ and $1 \mu \mathrm{m}$ Nuclepore filters and finally through a GF/F (Whatman) filter Pressure heads during fractionation never exceeded $0.004 \mathrm{~atm}$. Fluorescence was measured before and after acidification with $50 \mu \mathrm{l}$ of $1 \mathrm{~N}$ $\mathrm{HCl}$. The fluorometer was calibrated using a Sigma chl a standard.

Environmental data. Water temperature and salinity measurements were obtained with a Hydrolab sensor

Dissolved nutrient $\left[\mathrm{NH}_{4}, \mathrm{NO}_{2}, \mathrm{NO}_{3}, \mathrm{Si}\left(\mathrm{OH}_{4}\right), \mathrm{PO}_{4}\right]$ concentrations were determined shortly after sampling in a field laboratory using the standard techniques described by Strickland \& Parsons (1972). Surface irradiance was recorded during incubations with a Li-Cor solarimeter, and daily production estimated by dividing the production measured during the incubation period by the fraction of total daily irradiance during that period or, in case of a lack of light energy data, by multiplying hourly production by 10 .

\section{RESULTS}

Environmental characteristics affecting phytoplankton productivity. In Takapoto, lagoonal water temperature varied between $27^{\circ} \mathrm{C}$ during the dry season (July to September) and $30^{\circ} \mathrm{C}$ during the months of March and April, with an average of $29.0^{\circ} \mathrm{C}$. Salinity varied between 37 and 39.5 psu, depending on the precipitation, with an average of 38.2 psu. In Tikehau, lagoon water temperatures were similar (average $28.5^{\circ} \mathrm{C}$, Charpy 1985) but salinity was lower (35.5 psu, Charpy 1985). We have no precipitation (P) or evaporation (E) data for Takapoto or Tikehau, but Magner \& Wauthy (1976) estimated that $\mathrm{E}-\mathrm{P}=0.5 \mathrm{~m} \mathrm{yr}^{-1}$ in Takapoto. The evaporation-precipitation budget is probably the same in Takapoto and Tikehau and the difference in salinity reflects different lagoon-ocean exchanges.

Nutrient concentrations measured in Takapoto and Tikehau lagoons are summarized in Table 1. In November and February, ammonium and nitrate concentrations in Takapoto lagoon were generally $<0.2 \mu \mathrm{M}$, except at Stn 1, located close to the village, where concentrations up to 0.25 and $0.4 \mu \mathrm{M}$, respectively, were measured. No difference was noted relative to surface oceanic waters. Phosphate and silicate concentrations in the Takapoto lagoon were $<0.05$ and $0.5 \mu \mathrm{M}$, respectively. These levels are one-half to one-quarter of those in surface oceanic water (Fig. 2). Registered daily insolation (PAR) varied from $21 \mathrm{E} \mathrm{m}^{-2} \mathrm{~d}^{-1}$ in May to $53 \mathrm{E} \mathrm{m}^{-2} \mathrm{~d}^{-1}$ in September and February. Underwater light levels at $25 \mathrm{~m}$ (average depth of the lagoon) averaged $7.4 \%$ of surface irradiance.

In Tikehau, $\mathrm{PO}_{4}$ and $\mathrm{NH}_{4}$ concentrations were 2 times and 6 times higher, respectively, than in Takapoto. Incident light energy at Tikehau varied between 30 and $60 \mathrm{E} \mathrm{m}^{-2} \mathrm{~d}^{-1}$ (Fig 3), and $17 \%$ of the surface energy reached $25 \mathrm{~m}$ (average lagoon depth).

Table 1. Average $\pm \mathrm{SE}$ nutrient concentrations ( $\mu \mathrm{M}$ ) in Takapoto (November and February) and Tikehau (January and March) lagoons

\begin{tabular}{|lccccc|}
\hline Atoll & $\mathrm{PO}_{4}$ & $\mathrm{NO}_{2}$ & $\mathrm{NO}_{3}$ & $\mathrm{NH}_{4}$ & $\mathrm{SiO}_{2}$ \\
\hline Takapoto & $\begin{array}{c}0.07 \pm 0.012 \\
(\mathrm{n}=44)\end{array}$ & $\begin{array}{c}0.05 \pm 0.005 \\
(\mathrm{n}=35)\end{array}$ & $\begin{array}{c}0.19 \pm 0.023 \\
(\mathrm{n}=44)\end{array}$ & $\begin{array}{c}0.19 \pm 0.012 \\
(\mathrm{n}=44)\end{array}$ & $0.53 \pm 0.044$ \\
Tikehau & $\begin{array}{c}0.14 \pm 0.006 \\
(\mathrm{n}=351)\end{array}$ & $\begin{array}{c}0.02 \pm 0.001 \\
(\mathrm{n}=309)\end{array}$ & $\begin{array}{c}0.07 \pm 0.006 \\
(\mathrm{n}=313)\end{array}$ & $\begin{array}{c}1.26 \pm 0.099 \\
(\mathrm{n}=225)\end{array}$ & $0.83 \pm 0.025$ \\
& & & & $(\mathrm{n}=249)$ \\
\hline
\end{tabular}



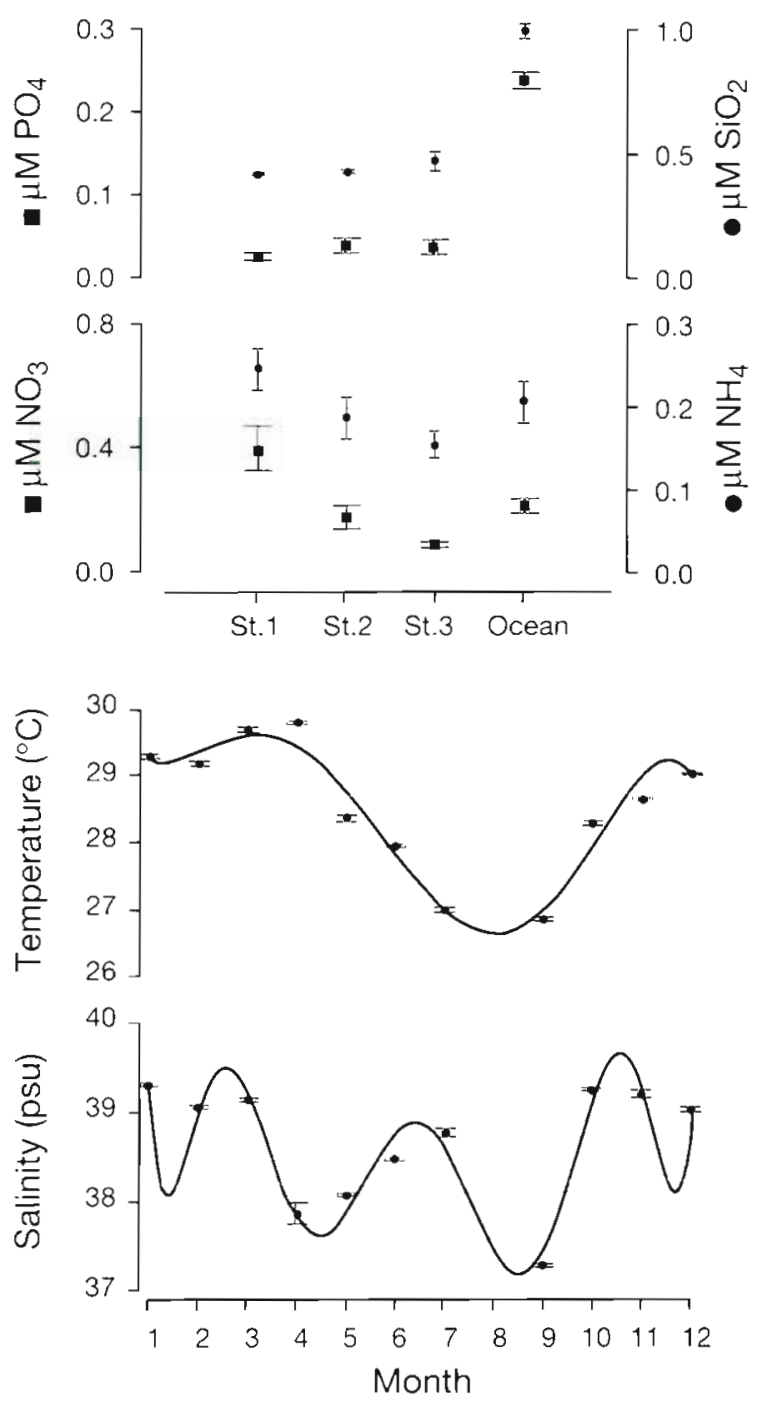

Fig. 2. Average ( $\pm \mathrm{SE}$ ) dissolved inorganic nutrient concentrations at 3 stations in Takapoto lagoon and one station located in surrounding surface oceanic waters (Ocean), and monthly averages ( \pm SE) of temperature and salinity between 1991 and 1993

Parameters of $\mathrm{C}$ uptake measurements. The average $\Sigma \mathrm{CO}_{2}$ concentration measured at the beginning of the experiments was $88.2 \pm 0.2 \mathrm{mg} \mathrm{l}^{-1}(\mathrm{n}=39)$. Dark assimilation never exceeded $10 \%$ of the light uptake, and variability of $C$ uptake among 3 sub-samples per depth was $<12 \%$ of their average.

Comparison between total production and biomass estimated by direct filtration and by the sum of the size class fractions (Takapoto). The integrated production of the 3 size fractions (>10 $\mu \mathrm{m}+10-2 \mu \mathrm{m}+$ $2-0.2 \mu \mathrm{m}$ ) was highly correlated with the production estimated from direct filtration through a $0.2 \mu \mathrm{m}$ filter (Fig. 4). A similar pattern was observed between primary production and the chlorophyll biomass where the sum of the size fractions $(>3 \mu m+3-1 \mu m+$
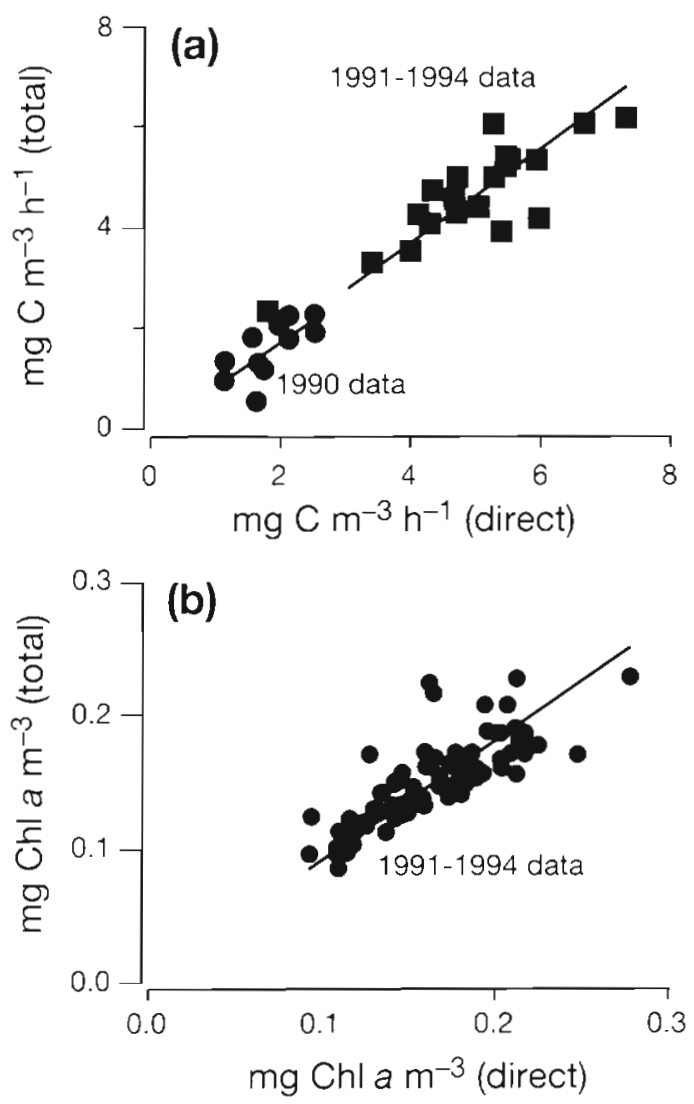

Fig. 4. Comparisons of direct filtration on to $0.2 \mu \mathrm{m}$ (1990 data) and GF/F filters (1991 to 1994 data) with total filtration: $>10 \mu \mathrm{m}+10-2 \mu \mathrm{m}+2-0.2 \mu \mathrm{m}(1990)$ and $>3 \mu \mathrm{m}+3-1 \mu \mathrm{m}+$ $1 \mu \mathrm{m}-\mathrm{GF} / \mathrm{F}$ (1991 to 1994) for (a) primary production and

(b) chl a. Lines are linear regressions

Fig. 3. Monthly average of incident light energy in Tikehau (1991) 
$1 \mu \mathrm{m}-\mathrm{GF} / \mathrm{F}$ ) was not statistically different from the biomass and production estimated from direct filtration through a $G F / F$ filter.

Vertical distributions of biomass and productivity. With 2 exceptions (profiles 04/90 and 10/90b), vertical profiles of chlorophyll and photosynthesis measured in Takapoto in 1990 (Fig. 5) had photosynthesis maxima at $10 \mathrm{~m}$ depth. Maximal photosynthesis rates were consistently $<3 \mathrm{mg} \mathrm{C} \mathrm{m}^{-3} \mathrm{~h}^{-1}$. In 1991 to 1994, however, 2 different situations could be observed in the Takapoto lagoon (Fig. 6). Under windy conditions (the most common), phytoplankton biomass was evenly distributed in the water column and exhibited production maxima in the upper $10 \mathrm{~m}$ (profiles 06/91 to 02/94c). Under calm conditions (November 1994), biomass and production maxima were found between 15 and $25 \mathrm{~m}$ (profiles $11 / 94 \mathrm{a}$ to $11 / 94 \mathrm{~d}$ ). Maximum photosynthesis rates up to $6 \mathrm{mg} \mathrm{C} \mathrm{m}^{-3} \mathrm{~h}^{-1}$ were recorded. In most cases, photosynthesis and biomass profiles exhibited the same trend. Maximum integrated photosynthesis was not correlated with maximum incident light energy. For example, average light energy received at the surface during the June 1991 incubation (06/91) was $3.8 \mathrm{E} \mathrm{m}^{-2} \mathrm{~h}^{-1}$ and the integrated production (upper $25 \mathrm{~m}$ ) was $0.8 \mathrm{~g} \mathrm{C} \mathrm{m}^{-2} \mathrm{~d}^{-1}$; in February 1994 (02/94b), light energy was $7.8 \mathrm{E} \mathrm{m}^{-2} \mathrm{~h}^{-1}$ and integrated production was $0.5 \mathrm{~g} \mathrm{C} \mathrm{m}^{-2} \mathrm{~d}^{-1}$.

In Tikehau, representative vertical profiles of chlorophyll and photosynthesis measured between 1991 and 1994 (Fig. 7) showed a uniform distribution of phytoplankton biomass in the water column and a production maximum in the upper $10 \mathrm{~m}$. Maximum photosynthesis rates in profiles up to $6 \mathrm{mg} \mathrm{C} \mathrm{m}^{-3} \mathrm{~h}^{-1}$ were consistently measured.

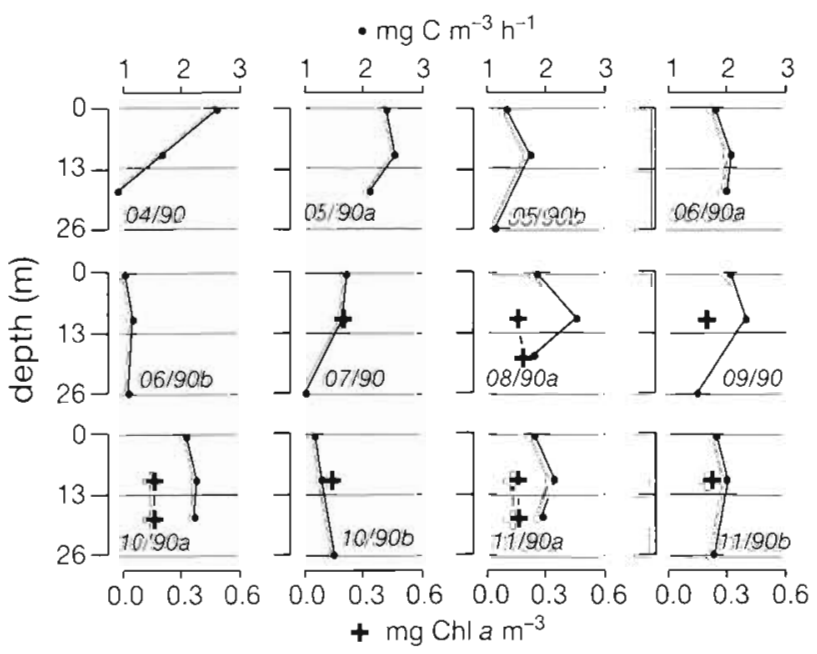

Fig. 5. Vertical profiles of carbon assimilation and chl a concentration in Takapoto in 1990. Example of nomenclature: $05 / 90 a=$ May 1990 first profile

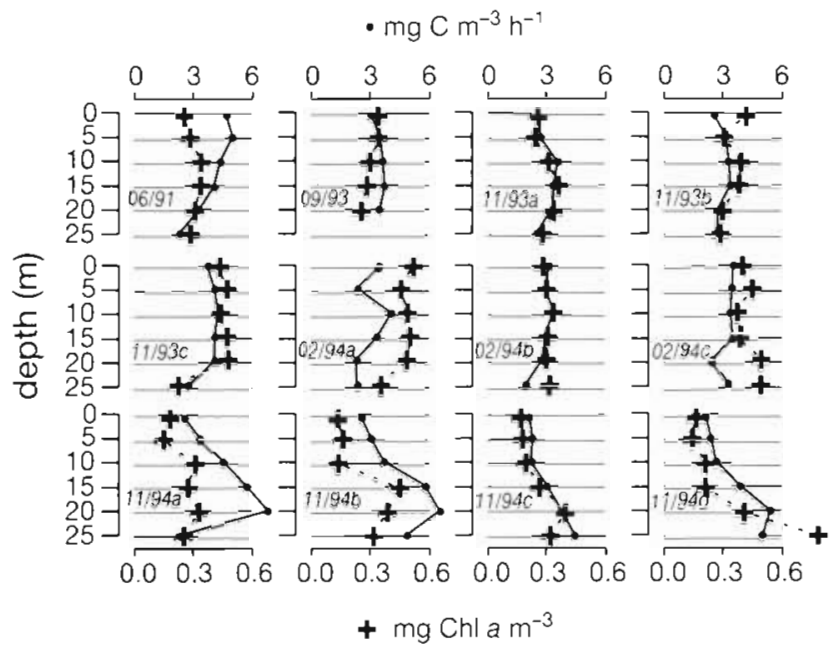

Fig. 6. Vertical profiles of carbon assimilation and chl a concentration in Takapoto between 1991 and 1994. Nomenclature as in Fig. 5

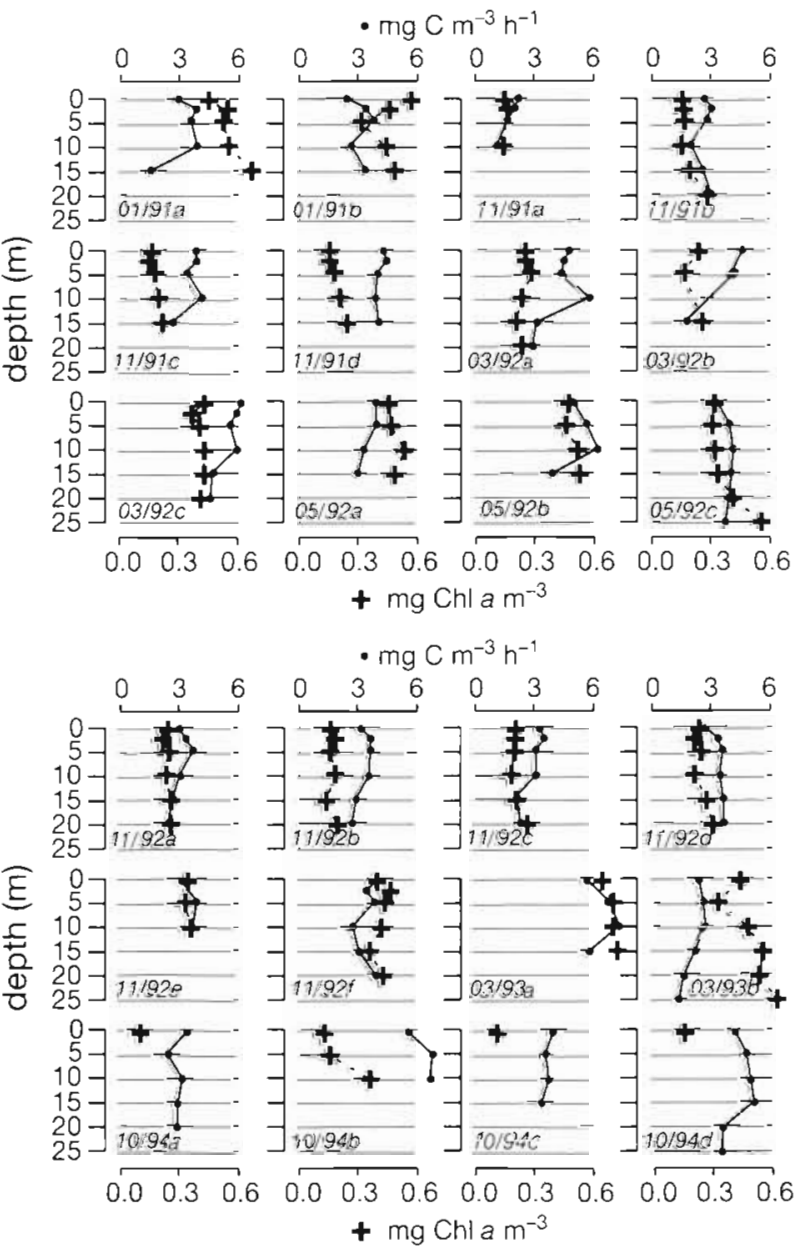

Fig. 7. Vertical profiles of carbon assimilation and chl a concentration in Tikehau between 1991 and 1994. Nomenclature as in Fig. 5 


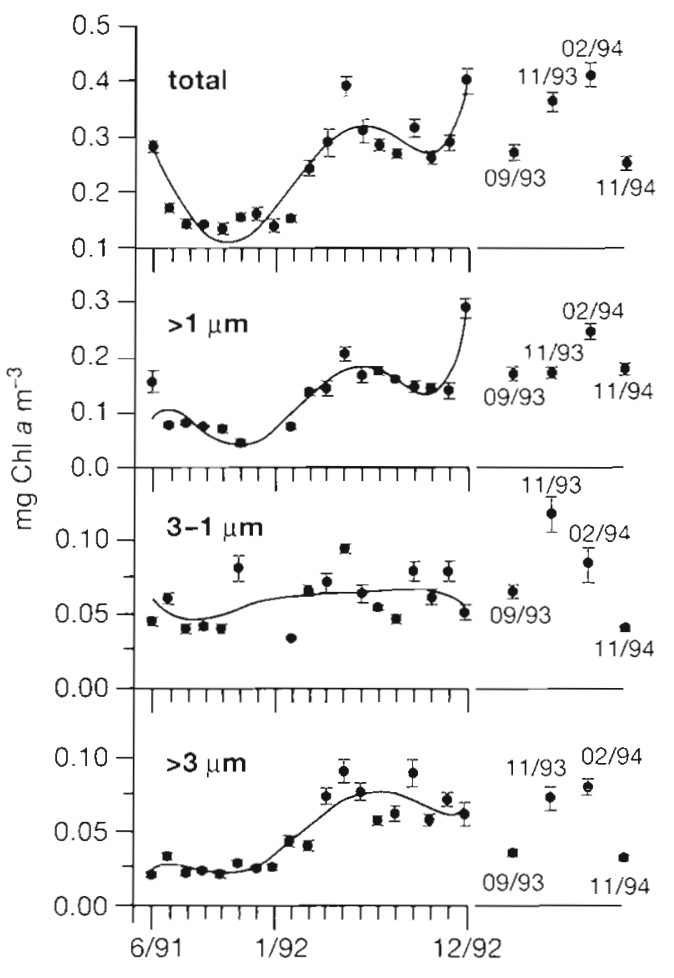

Fig. 8. Monthly average ( $\pm \mathrm{SE}$ ) of size-fractionated chl a in the 1991 to 1994 period in Takapoto. Example of nomenclature: 06/91 = June 1991

Seasonal productivity. Differences in phytoplankton biomass were observed in Takapoto lagoon between 1991 and 1994 (Fig. 8), mostly in the $<1 \mu \mathrm{m}$ and $>3 \mu \mathrm{m}$ size fractions. No significant change in standing crop levels of the 3-1 $\mu \mathrm{m}$ size fraction was observed. Chl a concentration was very low between July 1991 and February 1992, with monthly averages $<0.2 \mathrm{mg}$ chl a $\mathrm{m}^{-3}$ The highest daily (upper $10 \mathrm{~m}$ ) production rates (250 to $450 \mathrm{mg} \mathrm{C} \mathrm{m}^{-2} \mathrm{~d}^{-1}$ ) were observed in June 1991 and November 1993 in Takapoto (Fig. 9).

Size structure. Phytoplankton size structure was investigated in both Takapoto and Tikehau lagoons.

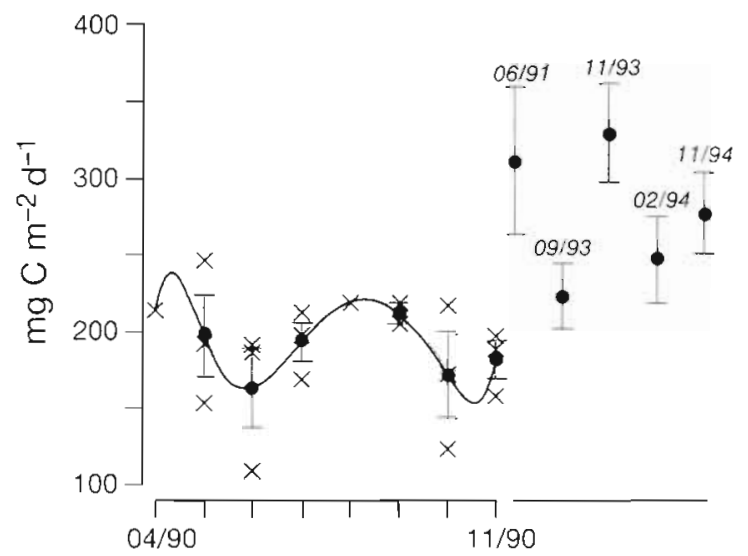

Fig. 9. Seasonal levels $(x)$ and average values $(\bullet) \pm S E$ of integrated primary production (upper $10 \mathrm{~m}$ ) in Takapoto. Values measured during the 1990 time series are connected for visual continuity. Nomenclature as in Fig. 8

Small phytoplankton dominated standing crop and primary production in both lagoons, regardless of season or depth. Contributions of the $<3 \mu \mathrm{m}$ fraction to primary production and biomass in the 2 lagoons (Table 2) were similar ( 80 and $82 \%$ for primary production and 81 and $78 \%$ for chl a standing crop). Phytoplankton in the $<1 \mu \mathrm{m}$ fractions in Takapoto and Tikehau lagoons contributed, respectively, 53 and $58 \%$ of primary production and 63 and $60 \%$ of chl a standing crop. During 1990 experiments in Takapoto, phytoplankton $>10 \mu \mathrm{m}, 10-2 \mu \mathrm{m}$ and $<2 \mu \mathrm{m}$ contributed $5.3 \pm 0.4 \%, 20.8 \pm 0.9 \%$ and $73.9 \pm 1.0 \%$. respectively, of total inorganic carbon uptake $(\mathrm{n}=$ 36).

Assimilation numbers. In Takapoto and Tikehau

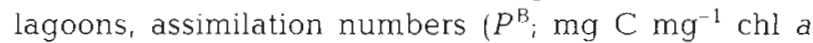
$\mathrm{h}^{-1}$ ) in size-fractionated samples varied with depth and size (Fig. 10). Maximum $P^{B}$ values in all size fractions were measured at $5 \mathrm{~m}$ depth, equivalent to $30 \%$ of irradiance levels.

Table 2. Percent contributions (mean $\pm \mathrm{SE}$ ) of different size fractions to primary production and chl a standing crop in lagoons during ${ }^{14} \mathrm{C}$ uptake measurements

\begin{tabular}{|c|c|c|c|c|c|c|c|c|}
\hline \multirow{4}{*}{ Takapoto 1990} & \multicolumn{4}{|c|}{${ }^{14} \mathrm{C}$ uptake } & \multicolumn{4}{|c|}{ Chl a } \\
\hline & $>10 \mu \mathrm{m}$ & $10-2 \mu \mathrm{m}$ & $<2 \mu \mathrm{m}$ & $<10 \mu \mathrm{m}$ & \multirow[b]{3}{*}{$>3 \mu \mathrm{m}$} & \multirow[b]{3}{*}{$3-1 \mu \mathrm{m}$} & \multirow[b]{3}{*}{$<1 \mu \mathrm{m}$} & \multirow[b]{3}{*}{$<3 \mu \mathrm{m}$} \\
\hline & $\begin{array}{l}5.3 \pm 0.4 \\
(n=36)\end{array}$ & $\begin{array}{c}20.8 \pm 0.9 \\
(n=36)\end{array}$ & $\begin{array}{c}73.9 \pm 1.0 \\
(\mathrm{n}=36)\end{array}$ & $\begin{array}{c}94.7 \pm 0.7 \\
(\mathrm{n}=36)\end{array}$ & & & & \\
\hline & $>3 \mu \mathrm{m}$ & $3-1 \mu \mathrm{m}$ & $<1 \mu \mathrm{m}$ & $<3 \mu \mathrm{m}$ & & & & \\
\hline Takapoto 1991-1994 & $\begin{array}{l}19.9 \pm 0.7 \\
(\mathrm{n}=108)\end{array}$ & $\begin{array}{c}27.0 \pm 0.7 \\
(\mathrm{n}=90)\end{array}$ & $\begin{array}{c}52.8 \pm 1.0 \\
(\mathrm{n}=90)\end{array}$ & $\begin{array}{l}80.1 \pm 0.7 \\
(n=108)\end{array}$ & $\begin{array}{l}19.2 \pm 0.4 \\
(n=386)\end{array}$ & $\begin{array}{c}23.0 \pm 0.5 \\
(n=386)\end{array}$ & $\begin{array}{l}57.6 \pm 0.4 \\
\{\mathrm{n}=386\}\end{array}$ & $\begin{array}{l}80.8 \pm 0.5 \\
(n=386)\end{array}$ \\
\hline Tikehau 1991-1994 & $\begin{array}{l}18.3 \pm 0.7 \\
(n=131)\end{array}$ & $\begin{array}{l}23.3 \pm 0.5 \\
(n=121)\end{array}$ & $\begin{array}{l}58.3 \pm 0.8 \\
(n=121)\end{array}$ & $\begin{array}{l}81.7 \pm 0.7 \\
(\mathrm{n}=131)\end{array}$ & $\begin{array}{c}22.4 \pm 0.9 \\
(\mathrm{n}=123)\end{array}$ & $\begin{array}{l}17.4 \pm 0.5 \\
(\mathrm{n}=113)\end{array}$ & $\begin{array}{c}60.1 \pm 0.9 \\
(n=113)\end{array}$ & $\begin{array}{l}77.6 \pm 0.9 \\
(n=123)\end{array}$ \\
\hline
\end{tabular}



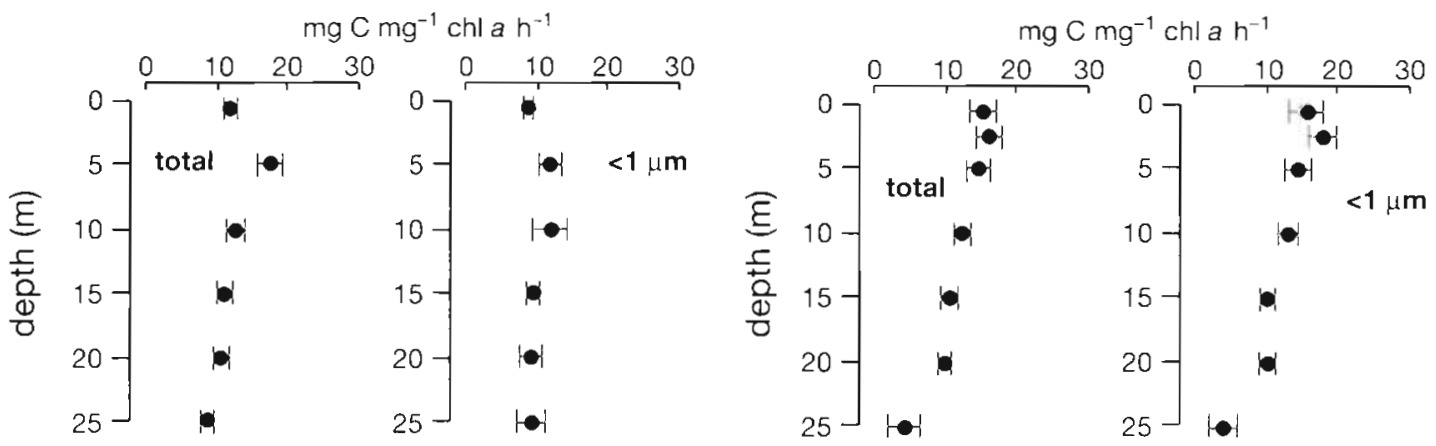

$\mathrm{mg} \mathrm{C} \mathrm{mg}^{-1} \mathrm{chl} \mathrm{a} \mathrm{h}^{-1}$
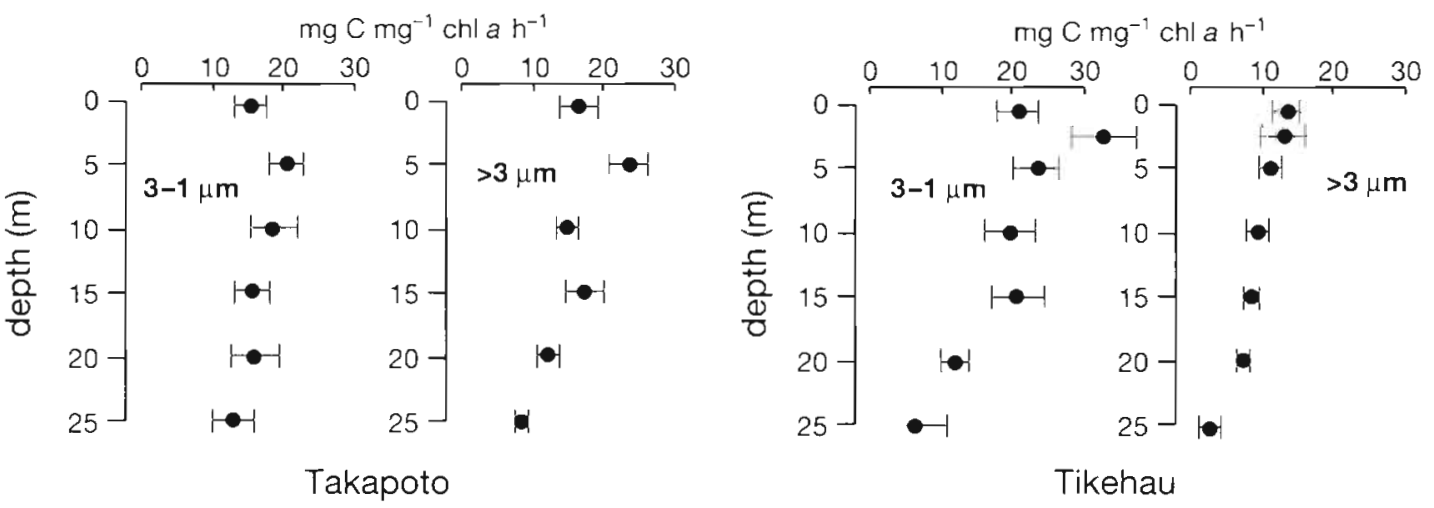

Fig. 10. Average ( \pm SE) vertical profiles of size-fractionated assimilation numbers between 1991 and 1994 in Takapoto and Tikehau lagoons

\section{DISCUSSION}

The slight increase in dissolved mineral nitrogen close to the village might reflect the contamination of lagoonal water by sewage.

As in Takapoto lagoon, phosphate and silicate concentrations in Tikehau were lower 10.1 and $0.8 \mu \mathrm{M}$ respectively) than in surface oceanic water $(0.4$ and $1.0 \mu \mathrm{M}$, respectively, Charpy-Roubaud et al. 1990). Depletion of reactive phosphorus and silicate concentrations in atoll lagoons below oceanic levels has been observed at a number of sites: in Canton Atoll lagoon (Smith \& Jokiel 1975), in Christmas Island lagoon (Smith et al. 1984) and in Takapoto atoll (Sournia \& Ricard 1976). Large quantities of nitrogen-fixing cyanobacteria inside atoll lagoons may be responsible for the P uptake (Charpy-Roubaud et al. 1996).

The very low level of chl a observed in Takapoto between July 1991 and February 1992 is difficult to explain. A spectacular bloom of small jellyfish Linuche unguiculata was observed during this period, but we do not know if there is a relation between this bloom and the low phytoplankton biomass. In Tikehau lagoon, proliferation of salps Thalia democratica had been observed in April 1985; their ingestion rate was $9 \mathrm{mg} \mathrm{C} \mathrm{m} \mathrm{m}^{-3} \mathrm{~d}^{-1}$, i.e. $50 \%$ of the $\mathrm{C}$ uptake by the phytoplankton (Le Borgne et al. 1989). Eleven surveys per- formed in Tikehau between 1983 and 1985 showed that large differences in chl a concentration were independent of season (Charpy \& Charpy-Roubaud 1991).

The 1991 to 1994 production rate in Takapoto was significantly higher than that of 1990 . Critical examinations of the ${ }^{14} \mathrm{C}$ uptake method (Fitzwater et al. 1982, Marra \& Heinemann 1984, Chavez \& Barber 1987) have shown that the choice of water sampling and incubation techniques may lead to significant differences in measured primary production rates. This was not appreciated in 1990, while between 1991 and 1994 considerable care was taken to maximize procedural cleanliness and process water samples in a clean manner using polycarbonate incubation bottles. An estimate of average lagoon production can be calculated by integrating the $25 \mathrm{~m}$ (average lagoon depth) profile experiments. If we consider only the 1991 to 1994 period for annual primary production estimation, daily primary production values in Takapoto ranged between 0.4 and $1.2 \mathrm{~g} \mathrm{C} \mathrm{m}^{-2} \mathrm{~d}^{-1}$ with an average of $0.8 \pm 0.1 \mathrm{~g} \mathrm{C} \mathrm{m}^{-2} \mathrm{~d}^{-1}$. In Tikehau, daily primary production values ranged between 0.4 and $1.1 \mathrm{~g} \mathrm{C} \mathrm{m}^{-2} \mathrm{~d}^{-1}$ with an average of $0.7 \pm 0.1 \mathrm{~g} \mathrm{C} \mathrm{m}^{-2} \mathrm{~d}^{-1}$. Therefore, annual production for Takapoto and Tikehau can be estimated respectively to be 292 and $250 \mathrm{~g} \mathrm{C} \mathrm{m}^{-2}$.

Daily phytoplankton production estimates for Takapoto and Tikehau lagoons fall in the upper end of the 
Table 3. Values for phytoplankton community daily production in atoll lagoons. In part from Sorokin (1990)

\begin{tabular}{|lll|}
\hline Location & $\mathrm{g} \mathrm{C} \mathrm{m}{ }^{-2} \mathrm{~d}^{-1}$ & \multicolumn{1}{c|}{ Source } \\
\hline Rongelap atoll (Marshall Islands) & 0.2 & Sargent \& Austin (1949) \\
Eniwetok atoll (Marshall Islands) & 0.03 & Sargent \& Austin (1954) \\
Fanning atoll (Line Islands) & 0.1 & Gordon et al. (1971) \\
Ngellelevu atoll (Fiji) & $0.01-0.03$ & Sorokn (1979) \\
Tarawa atoll (Kiribati) & $0.03-0.5$ & Sorokin (1971) \\
Butaritari atoll (Kiribat) & $0.02-0.30$ & Sorokin (1971) \\
Majuro atoll (Marshall Islands) & $0.01-0.40$ & Sorokin (1973a) \\
Ninigo atoll (Admiralty Islands) & $0.16-0.72$ & Sorokin (1973b) \\
Sinton atoll (South China Sea) & $0.02-0.60$ & Sorokin \& Tyapkin (1984) \\
Spratly Is. (South China Sea) & $0.02-0.20$ & Sorokin \& Tyapkin (1984) \\
Scott Reef (Timor Sea) & $0.01-0.20$ & Sorokin (1979) \\
Coetivy Is. (Seychelles) & $0.02-0.24$ & Sorokin \& Tyapkin (1984) \\
Curtaun Reef (Caribbean Sea) & $0.01-0.05$ & Milliman \& Mahnken (1972) \\
Cayos de Albuquerque (Caribbean Sea) $0.01-0.10$ & Milliman \& Mahnken (1972) \\
Laccadives atoll & $0.02-0.09$ & Quasum et al. (1972) \\
Scilly atoll (French Polynesia) & 0.4 & Ricard \& Delesalle (1981.) \\
Takapoto atoll & 0.4 & Sournia \& Ricard (1976) \\
Mataiva atoll (French Polynesia) & $0.18-0.72$ & Delesalle et al. (1985) \\
Tikehau (1983-1987) & 0.44 & Charpy-Roubaud et al. (1989) \\
Rangiroa atoll (French Polynesia) & 0.45 & Charpy (unpubl.) \\
Toau atoll (French Polynesla) & 0.1 & Charpy (unpubl.) \\
Takapoto (1991-1994) & 0.8 & This study \\
Tikehau (1991-1994) & 0.7 & This study \\
& & \\
\hline
\end{tabular}

Plankton $<1 \mu \mathrm{m}$ were the dominant size fraction of Takapoto and Tikehau lagoon phytoplankton populations in biomass ( 63 and $60 \%$ ) and production (53 and $58 \%$ ).

Sieburth et al. (1978) considered that the picoplankton is composed of organisms with a size $<2 \mu \mathrm{m}$. We can estimate the contribution of these organisms to the primary production in Takapoto using 1990 data: the picoplankton $(<2 \mu \mathrm{m})$ contributed $74 \%$ of the phytoplankton production. This value is slightly higher than those given by Furnas et al. (1990) for lagoons of the central Great Barrier Reef ( 47 to $69 \%$ ).

The average $P^{B}$ of the fractions collected by $\mathrm{GF} / \mathrm{F}$ filters were very close in Takapoto $(13.0 \pm 0.6 ; n=108)$ and Tikehau $(13.3 \pm 0.7 ; n=126)$ (Table 4$)$. The ranges of assimilation numbers observed in both lagoons were very high and indicate that phytoplankton were growing at high rates. Such $p^{8}$ values are commonly measured in range of phytoplankton production recorded in atoll lagoon ecosystems (Table 3). However, the majority of the results summarized in Table 3 were not obtained with clean procedures. These new estimations of primary production in Takapoto and Tikehau lagoons are 2 times higher than estimates given by Sournia \& Ricard (1975) and Charpy-Roubaud et al. (1989).

The relationship between light and primary production in Takapoto seems to be different from that which we would have expected from the light-primary production model constructed for Tikehau lagoon by Charpy \& Charpy-Roubaud (1990a). Phytoplankton physiological state or grazing effect during the incubations may explain the difference.

Phytoplankton production rates in the lagoon varied without discernible seasonality as also observed by Furnas \& Mitchell (1987) in outer-shelf waters of the central Great Barrier Reef. subtropical intrusive systems (Yoder et al. 1985), upwelling zones (Malone 1980), coastal waters (Harrison \& Platt 1980), and other atolls or close to Pacific islands (Gordon et al. 1971, Sournia \& Ricard 1976, Ricard \& Delesalle 1981, Delesalle et al. 1985, Legendre et al. 1988).

Community carbon doubling rates per day $(\mu)$ were estimated from the $P^{\mathrm{B}}$ per day and the C/chl a ratio of

$$
\mu=\log _{2}\left(\frac{\mathrm{C} / \mathrm{chl} a+P^{B}}{\mathrm{C} / \mathrm{chl} a}\right)
$$

Phytoplankton in Takapoto and Tikehau are dominated by Synechococcus (Blanchot et al. 1989, Charpy et al. 1992, Charpy \& Blanchot 1996). Therefore, we use the Synechococcus C/chl a ratio of 82 calculated for Takapoto by Charpy et al. (1992) using a C/volume ratio of $0.4 \mathrm{pg} \mathrm{C} \mathrm{mm}^{-3}$ and an average cell diameter of the phytoplankton by the equation of Eppley (1972):

Table 4. Average $\pm \mathrm{SE}$ assimilation number $\left(P^{\beta} ; \mathrm{mg} \mathrm{C} \mathrm{mg-1}^{-1} \mathrm{chl} a \mathrm{~h}^{-1}\right)$ and doubling rate per day $(\mu)$ of different size fractions

\begin{tabular}{|c|c|c|c|c|c|c|c|}
\hline \multirow{2}{*}{ Lagoon } & \multicolumn{4}{|c|}{$p^{\mathrm{B}}$} & \multicolumn{3}{|c|}{$\mu\left(\mathrm{d}^{-1}\right)$} \\
\hline & $>3 \mu \mathrm{m}$ & $3-1 \mu \mathrm{m}$ & $<1 \mu \mathrm{m}$ & Total & $>3 \mu \mathrm{m}$ & $3-1 \mu \mathrm{m}$ & $<1 \mu \mathrm{m}$ \\
\hline Takapoto & $\begin{array}{c}16.9 \pm 1.1 \\
(\mathrm{n}=93)\end{array}$ & $\begin{array}{c}17.0 \pm 1.1 \\
(\mathrm{n}=89)\end{array}$ & $\begin{array}{c}1.0 .5 \pm 0.6 \\
(\mathrm{n}=89)\end{array}$ & $\begin{array}{l}13.0 \pm 0.6 \\
(n=108)\end{array}$ & $\begin{array}{c}1.51 \pm 0.05 \\
(n=93)\end{array}$ & $\begin{array}{c}1.50 \pm 0.06 \\
(\mathrm{n}=89)\end{array}$ & $\begin{array}{c}1.13 \pm 0.04 \\
(\mathrm{n}=89)\end{array}$ \\
\hline Tikehau & $\begin{array}{l}10.7 \pm 0.8 \\
(n=126)\end{array}$ & $\begin{array}{l}21.2 \pm 1.5 \\
(n=111)\end{array}$ & $\begin{array}{l}13.5 \pm 0.8 \\
(n=113)\end{array}$ & $\begin{array}{l}13.3 \pm 0.7 \\
(n=126)\end{array}$ & $\begin{array}{c}1.22 \pm 0.06 \\
(\mathrm{n}=1.14)\end{array}$ & $\begin{array}{l}1.69 \pm 0.07 \\
(n=113)\end{array}$ & $\begin{array}{c}1.32 \pm 0.05 \\
(\mathrm{n}=113)\end{array}$ \\
\hline
\end{tabular}


Table 5. Summary of Takapoto and Tikehau lagoon characteristics during the 1991 to 1994 period. A: lagoon area $\left(\mathrm{km}^{2}\right)$; AD: average depth $(\mathrm{m})_{i} \mathrm{~S}$ : salinity $(\mathrm{psu})$; $\mathrm{T}$ temperature $\left({ }^{\circ} \mathrm{C}\right)$; $\mathrm{RT}$ : residence time $(\mathrm{yr}) ; \mathrm{PO}_{4}$ : phosphate concentration $(\mu \mathrm{M})$; $\mathrm{Chl}$ a: chlorophyll a concentration ( $\left.\mathrm{mg} \mathrm{m}^{-3}\right)$; PP: primary production $\left(\mathrm{g} \mathrm{C} \mathrm{m}^{-2} \mathrm{~d}^{-1}\right) ; \mu_{<1}$ im doubling rate per day of the $<1 \mu \mathrm{m}$ fraction

\begin{tabular}{|c|c|c|c|c|c|c|c|c|c|c|c|}
\hline Lagoon & $A$ & $A D$ & $S$ & $\mathrm{~T}$ & RT & $\mathrm{PO}_{4}$ & Chl a & PP & Chl $a<3 \mu \mathrm{m}$ & $\mathrm{Chl} a<1 \mu \mathrm{m}$ & $\mu_{<1 \mu \mathrm{m}}$ \\
\hline Takapoto & 80 & 25 & 38.2 & 29.0 & $6^{\circ}$ & 0.1 & 0.27 & 0.8 & $81 \%$ & $58 \%$ & $1.13 \mathrm{~d}^{-1}$ \\
\hline Tikehau & 400 & 25 & 35.5 & 28.5 & $0.5^{b}$ & 0.2 & 0.32 & 0.7 & $78 \%$ & $60 \%$ & $1.32 \mathrm{~d}^{-1}$ \\
\hline
\end{tabular}

$0.8 \mu \mathrm{m}$. Mean carbon doubling rates in different size classes are summarized in Table 4 . All size fractions exhibited rapid division rates with averages in the range 1.13 to $1.69 \mathrm{~d}^{-1}$ However, the $>1 \mu \mathrm{m}$ fractions, which had the shortest generation times ( 0.6 to $0.7 \mathrm{~d})$, consist of microalgae and Synechococcus doublet cells, and the $\mathrm{C} / \mathrm{chl}$ a ratio of 82 calculated for Synechococcus cannot be applied here. Therefore, we will consider only that $<1 \mu \mathrm{m}$ fraction which was numerically dominated by Synechococcus. Average doubling rates for this fraction were significantly different in Takapoto $\left(1.13 \pm 0.04 \mathrm{~d}^{-1}\right)$ and Tikehau $\left(1.32 \pm 0.05 \mathrm{~d}^{-1}\right)$. These values are high, but lower than the maximal doubling rate of $\mathrm{chl}$ ( $\mu_{\max }=$ $\left.1.6 \mathrm{~d}^{-1}\right)$ measured in the tropical shelf waters of the Great Barrier Reef by Furnas (1991).

Takapoto and Tikehau lagoon characteristics are summarized in Table 5. In spite of a large difference in the residence times of the 2 lagoon systems ( 4 yr for Takapoto and $0.5 \mathrm{yr}$ for Tikehau), phytoplankton biomass and productivity were quite similar. The linear relationship between residence time and phytoplankton biomass expressed as chlorophyll concentrations observed in some French Polynesia lagoons by Delesalle \& Sournia (1992) cannot be applied for production. However, these authors consider that such a relationship may not be applicable for residence times longer than $50 \mathrm{~d}$.

\section{CONCLUSIONS}

Takapoto and Tikehau atoll lagoons are characterized by low nutrient levels, low phytoplankton biomass, but high biomass-specific productivity. The dominance of picoplankton in biomass $(80 \%>3 \mu \mathrm{m})$ and production $(60 \%<1 \mu \mathrm{m})$ is probably a characteristic of Tuamotu atoll lagoons. The dominant fraction $(<1 \mu \mathrm{m})$ grew 1.2 times faster in Tikehau than in Takapoto. Average daily primary production rates were estimated to be 0.8 and $0.7 \mathrm{~g} \mathrm{C} \mathrm{m}^{-2}$, respectively. However, the relatively low biomass of phytoplankton and its small size has to be taken into account when estimating the capacity of these lagoons to support an extensive aquaculture
Acknowledgements. This work was carried out in French Polynesia within the framework of the General Research Program on the Pearl Oyster (Contract 1989-1993) with the financial participation of the French DOM-TOM Ministry, the French Ministry for Research and Technology, the European Fund (VI FED-PTOM) and the territorial government of French Polynesia. I thank L. Lo, J.-P. Rochette, A. Pellan and G. Haumani, director of the EVAAM station in Takapoto, as well as his entire team for technical help in the field and in the lab. I also express my gratitude for the comments of the anonymous reviewers and Miles Furnas.

\section{LITERATURE CITED}

Blanchot J, Charpy L, Le Borgne R (1989) Size composition of particulate organic matter in the lagoon of Tikehau atoll (Tuamotu archipelago). Mar Biol 102:329-339

Charpy L (1985) Distribution and composition of particulate organic matter in the lagoon of Tikehau (Tuamoto archipeligo, French Polynesia). Proc 5th Int Coral Reef Symp, Tahiti 3:353-357

Charpy L (1992) The CYEL program: energy flow and organicmatter cycling in atoll lagoons. UNEP Reg Seas Rep Stud $147: 69-75$

Charpy L (1994) La productivité des lagons. Les journées internationales de la perle et du bijou de Tahiti. EVAAM, Tahiti, p 3 (Abstract)

Charpy L, Blanchot J (1996) Prochlorococcus contribution to phytoplankton biomass and production of Takapoto atoll (Tuamotu archipelago). CR Acad Sci Paris Sér III Life Sci 319:131-137

Charpy L, Blanchot J, Lo L (1992) Contribution des cyanobactéries (Synechococcus spp.) à la production phytoplanctonique dans un lagon d'atoll fermé (Takapoto, Tuamotu, Polynésie Française). CR Acad Sci Sér III Sci Vıe 314: 395-401

Charpy L, Charpy-Roubaud CJ (1990a) A model of the relationship between light and primary production in an atoll Lagoon. J Mar Biol Ass UK 70:357-369

Charpy L, Charpy-Roubaud CJ (1990b) Trophic structure and productivity of the lagoonal communitues of Tikehau atoll (Tuamotu Archipelago, French Polynesia). Hydrobiologia 207:43-52

Charpy L, Charpy-Roubaud CJ (1991) Particulate organic matter fluxes in a Tuamotu atoll lagoon (French Polynesia). Mar Ecol Prog Ser 71:53-63

Charpy L, Harmelin-Vivien M (1992) Prelıminary results on production and calcification of coral reef communities of Tikehau atoll. ORSTOM Tahiti, Notes et Doc Océanogr 44: $1-20$

Charpy-Roubaud CJ, Charpy L, Cremoux JL (1990) Nutrient budget of the lagoonal waters in an open South Pacific 
atoll (Tikehau, Tuamotu, French Polynesia). Mar Bıol 107. $67-73$

Charpy-Roubaud CJ, Charpy L, Larkum AW (1996) Contribution of $\mathrm{N}_{2}$ fixation to $\mathrm{N}$ productivity of the lagoon of Tikehau. Proc 8th Int Coral Reef Symp, Panama, in press

Charpy-Roubaud CJ, Charpy L, Lemasson L (1989) Benthic and planktonic primary production of an open atoll lagoon (Tikehau, French Polynesia). Proc 6th Int Coral Reef Symp Townsville 2:551-556

Chavez FP, Barber RT (1987) An estimate of new production in the equatorial Pacific. Deep Sea Res 34:1229-1244

Chisholm JRM, Gattuso JP (1991) Validation of the alkalinity anomaly technique for investigating calcification and photosynthesis in coral reef communities. Limnol Oceanogr $36: 1232-1239$

Delesalle B and 11 co-authors (1985) Environmental survey of Mataiva Atoll. Tuamotu Archipelago, French Polynesia. Atoll Res Bull 286:1-34

Delesalle B, Sournia A (1992) Residence time of water and phytoplankton biomass in coral reef lagoons. Cont Shelf Res 12:939-949

Eppley RW (1972) Temperature and growth in the sea. Fish Bull US 70:1063-1085

Fitzwater SE, Knauer GA, Martin JH (1982) Metal contamination and its effect on primary production measurements. Limnol Oceanogr 27:544-551

Furnas MJ (1987) Effects of pre-screening on phytoplankton size-fraction productivity. Limnol Oceanogr 32:483-491

Furnas MJ (1.991) Net in situ growth rates of phytoplankton in an ohgotrophic, tropical shelf ecosystem. Limnol Oceanogr $36: 13-29$

Furnas MJ, Mitchell AW (1987) Phytoplankton dynamics in the central Great Barrier Reef. II Primary production. Cont Shelf Res 7:1049-1062

Furnas MJ, Mitchell AW, Gilmartin M, Revelante N (1990) Phytoplankton biomass and primary production in semienclosed reef lagoons of the central Great Barrier Reef, Australia. Coral Reefs 9:1-10

Gordon DC Jr, Fournier RO, Krasn..ck GJ (1971) Note on the planktonic primary production in Fanning Island Lagoon. Pac Sci 25:228-233

Harrison WG, Platt T (1980) Variations in assimilation number of coastal marine phytoplankton: effects of environmental co-variates. J Plankton Res 2:249-260

Intes A (1984) Présentation gémérale de l'atoll. In: Intes A (ed) L'atoll de Tikehau (archipel des Tuamotu, Polynésie Française). Premers résultats, ORSTOM Tahiti, Notes et Doc Océanogr 22:4-12

Le Borgne RP, Blanchot J, Charpy L. (1989) Zooplankton of the atoll of Tikehau (Tuamotu Archipelago) and its relationship to particulate matter. Mar Biol 102:341-353

Legendre L, Demers S, Delesalle B, Harnois C (1988) Biomass and photosynthetic activity of phototropje picoplankton in coral reef waters (Moorea Island, French Polynesı). Mar Ecol Prog Ser 47:153-160

Lenhardt X (1991) Hydrodynamique des lagons d'atoll et d'ìle haute en Polynésie Française. ORSTOM. Etude et These. Paris, $p 132$

Magner Y, Wauthy B (1976) Esquisse hydrologique du lagon de Takapoto (Tuamotu). Cah ORSTOM, Série Océanographie 14:279-284

Malone TC (1980) Size fractionated primary productivity of marine phytoplankton. In: Falkowski PG (ed) Primary productuvity in the sea. Plenum Press, New York, p $301-320$

Marra JH, Heinemann KR (1.984) A comparison between noncontaminating and conventional incubation procedures in primary production measurements. Limnol Oceanogr 29: $389-392$

Milliman JD, Mahnken C (1972) Reef productivity measurements. Atoll Res Bull 129:23-27

Perez FF, Fraga F (1987) A precise and rapid analytical procedure for alkalinity determination. Mar Chem 21:169-182

Qasim SZ, Bhattathiri PMA, Reddy CVG (1972) Primary production of an atoll in the Laccadives. Int Rev Ges Hydrobiol 57:207-225

Ricard M, Delesalle B (1981) Phytoplankton and primary productivity of the Scilly lagoon waters. Proc 4th Int Coral Reef Symp, Manila 1:425-429

Riley JP, Skirrow G (eds) (1975) Chemical oceanography, 2nd edn. Academic Press, London

Sargent MC, Austin TS (1949) Organic productivity of an atoll. Trans Am Cieophys Un 30(2):245-249

Sargent MC, Austin TS (1954) Biological economy of coral reefs. Organic productivity of an atoll. US Dept of the Interior, Washington Geol Survey 260-e:293-301

Sieburth JMN, Smetacek V, Lenz J (1978) Pelagic ecosystem structure: heterotrophic compartments of the plankton and their relationship to the plankton size fraction. Limnol Oceanogr 23:1256-1263

Smith SV, Chandra S, Kivitka L, Scheider RG, Schoonmaker J. Suto J, Tebano T. Trubble GW (1984) Chemical stoichlometry of lagoonal metabolism. Preliminary report on an environmental chemistry survey of Christmas Island, Kiribati. University of Hawaii Sea Grant Cooperative Rept UNIHI-SEAGRANT-CR-84-01

Smith SV, Jokiel PL (1975) Water composition and biogeochemical gradients in the Canton atoll lagoon: 1 Lagoon description; design of system analysis; salt and water budget. Mar Sci Comm 1(1):75-100

Sorokin YI (1971) O roli bacterii $v$ productivnosti soobschestva korallovogo rifa (On the role of bacteria in the productivity of coral reef community]. Zh Obshch Biol (J Gen Biol Moscow) 32:69-85 (in Russian)

Sorokin Yl (1973a) Characteristics of productivity of the Majuro atoll Marshall Islands. Oceanologiya 13:487-492 (English translation)

Sorokin YI (1973b) On the productivity of coastal tropical waters in the West Pacific. Oceanologiya 13:669-675 (English translation)

Sorokin YI (1979) Planktonnaya microflora i phytoplankton v vodakh korallovogo rifa. [Planktonic microflora and phytoplankton in the vicinity of coral reefs]. Zh Obshch Biol (J Gen Biol Moscow) 40:677-689 (in Russian)

Sorokin YI, Tyapkin VS (1984) Microheterotrophs in coastal waters of central Vietnam. Mar Bıol (Vladivostok) 4:15-23 (English translation)

Sournla $A_{1}$ Ricard M (1975) Production prmarre planctonique dans deux lagons de Polynésie Française (île de Moorea et atoll de Takapoto). CR Acad Sci Pans Sér D 280(6): $741-743$

Sournia A, Rıcard M (1976) Données sur l'hydrologie et la productivité du lagon d'un atoll fermé (Tuamotu, Iles Tuamotu). Vie Milleu 26(2):243-279

Strickland JDH, Parsons TR (1972) A practical handbook of seawater analysis, 2nd edn. Bull Fish Res Bd Can 167: $1-311$

Yentsch CS, Menzel DW (1963) A method for the determination of phytoplankton chlorophyll and phaeophytin by fluorescence. Deep Sea Res 10:221-231

Yoder JA, Atkinson LP, Bishop SS, Blanton JO, Lee TN, Pietrafesa LJ (1985) Phytoplankton dynamics within Gulf Stream intrusions on the southeastern United States continental shelf during summer 1981. Cont Shelf Res 4:611-635 